\title{
Serum Markers for the Prediction of Preeclampsia
}

\author{
George Daskalakis ${ }^{1}$ and Angeliki Papapanagiotou ${ }^{2 *}$ \\ ${ }^{1}$ Department of Obstetrics and Gynecology, Athens University, Athens, Greece \\ ${ }^{2}$ Department of Clinical Biochemistry, Athens University, Athens, Greece
}

"Corresponding author: George Daskalakis, Department of Clinical Biochemistry, Athens University, 1 Vas. Sophias \& 8 I. Metaxa Street 15236, P. Penteli, Athens, Greece, Tel: +306945235757; E-mail: gdaskalakis@yahoo.com

Received date: Aug 04, 2014, Accepted date: Jan 08, 2015, Published date: Jan 13, 2015

Copyright: ( 2014 Daskalakis G, et al. This is an open-access article distributed under the terms of the Creative Commons Attribution License, which permits unrestricted use, distribution, and reproduction in any medium, provided the original author and source are credited.

\begin{abstract}
Preeclampsia is one of the major causes of perinatal morbidity and mortality. There is urgent need for a first trimester marker for the prediction of the disease. Ultrasonographic markers when used alone are not very sensitive. Several biochemical serum markers have been investigated as possible predictors in the first and second trimester of pregnancy. The markers which have been studied extensively are both angiogenic and antiangiogenic factors as well as factors related to the process of placentation. However, the biochemical markers when they are used alone are not extremely effective for the prediction of PE. The combination of these markers with other predictors such as maternal history, clinical features, risk factors, demographic characteristics, uterine arteries Doppler will develop in the future more effective prediction models.
\end{abstract}

Keywords: Preeclampsia; Prediction; Serum biochemical markers

\section{Introduction}

Preeclampsia (PE) is a leading cause of maternal and perinatal morbidity and mortality worldwide affecting $3 \%$ to $5 \%$ of pregnant women [1] and it is associated with the development of cardiovascular disease, obesity, renal damage and diabetes in adults [2-4]. It is a systemic syndrome which clinically arises in the second half of pregnancy and it is presented with the onset of hypertension (arterial pressure exceeding $140 / 90 \mathrm{mmHg}$ on 2 occasion, at least 6 hours apart) and proteinuria $(>300 \mathrm{mg} / \mathrm{dL} / 24 \mathrm{~h}$ or a dipstick of $>=2+)$ after 20 weeks of gestation, in a previously normotensine women [5].

According to World Health Organization, in developing countries with limited access to health care, PE is estimated to be responsible for more than 60000 maternal deaths per year, whereas in the developed countries the burden of this disease falls on the neonates because of the high rate of iatrogenic preterm deliveries performed to preserve the maternal health [6]. The perinatal and neonatal mortality rate due to $\mathrm{PE}$ is about $10 \%$, worldwide [7].

In clinical practice, there is currently no reliable screening method in the first trimester of pregnancy with sufficient accuracy to identify women at high risk to develop PE despite the fact that many predisposing factors, including defective placentation, may already be apparent in the first or early second trimester. However, the ability of identification women at high-risk has increased considerably during the past decade. Early identification of high-risk pregnancy may help the development of new strategies for antenatal surveillance or prevention and thus improve maternal and perinatal outcome. The early identification of patients with increased risk for PE is therefore one of the most important goals in obstetrics. The aim of this study was to review the literature on the predictive serum markers of PE.

\section{Risk factors for preeclamsia}

A high number of pre-pregnancy and pregnancy related factors have been associated with PE. Several medical conditions, such as chronic hypertension, renal disease, pre-gestational diabetes mellitus, uncontrolled hyperthyroidism, polycystic ovary syndrome, urinary tract infections, connective tissue disease (rheumatoid arthritis, lupus erythematosus), obesity, insulin resistance, antiphospolipid syndrome and thrombophilia, are some of these factors [8,9]. Moreover, maternal low birth weight, primipaternity, pregnancies conceived after donor insemination, oocyte or embryo donation, limited sperm exposure of the mother, maternal infections, partner who fathered preeclamptic pregnancy with another woman and chromosomal abnormality (triplody, trisoimy 13) are risk factors for PE $[8,9]$. Conditions associated with increased placental mass, such as multifetal gestation and hydatidiform mole may also predispose to PE. Smoking during pregnancy has been found to decrease the risk of PE. In addition PE is higher in pregnant women younger than 20 and older than 40 years [10].

Maternal demographics including ethnic group, parity, body mass index (BMI), and personal or family history of PE are well-known risk factors [11]. Among women considered as high-risk, approximately $25 \%$ will develop PE compared to $5 \%$ in the general population [12]. The presence of PE in a first-degree relative increases a woman's risk of severe PE two to four fold [13], while a history of PE on fathers' mother increases the risk [14]. Most cases of PE occurs in nulliparous, in whom the incidence of PE may be as high as $7.5 \%$, but multiparous with a new partner seem to have similar risk for preeclampsia to that of nulliparous women [15]. Although risk factors are not useful as an effective screening test by themselves [16], they can help on the identification of high risk populations in which other predictive test may perform better $[17,18]$.

In a large study, Poon et al. showed that by using certain risk factors could predict early- and late-onset PE. Predictors of early-PE were black race, chronic hypertension, prior history of $\mathrm{PE}$ and the use of ovulation drugs. Late-PE predictors were advanced maternal age, 
Page 2 of 9

increased body mass index and family or personal history of PE. Using maternal factors the detection rates of early and late-PE were $37 \%$ and $28.9 \%$ respectively, for a $5 \%$ false positive rate [19].

\section{Pathogenesis}

The pathogenesis of preeclampsia is complicated and has not been fully elucidated. However, it is evident that this disorder involves multiple organ systems. Pathogenetic mechanisms implicated in preeclampsia include defective placentation, oxidative and endoplasmic reticulum stress, autoantibodies to type-1 angiotensin II receptor, platelet and thrombin activation, intravascular inflammation, endothelial dysfunction and the presence of an antiangiogenic state, among which an imbalance of angiogenesis has been emerged as one of the most important factors [20]. Angiogenesis is necessary for the establishment of adequate placental perfusion, which is important for providing the optimum in utero environment to support fetal development. Defective placental angiogenesis is associated with several pregnancy complications, the most clinically important of which is preeclampsia [21]. Nevertheless, it seems clear that placenta is the principal contributor to the pathogenesis of preeclampsia since the clinical syndrome will not develop in the absence of a placenta and the delivery of placenta remains the only treatment for the clinical disease.

Trophoblastic invasion has specific characteristics in human placentation. It is limited in depth, ending in the intern third of the myometrium and it is orientated to the spiral arteries. In normal pregnancies, extravillous cytotrophoblasts of fetal origin invade the uterine spiral arteries of the decidua and myometrium [22]. These invasive cytotrophoblasts replace the endothelial layer of the maternal spiral arteries, transforming them from small, high-resistance vessels into large-caliber vessels. These changes are essential to allow adequate blood supply to the placenta. In PE this transformation is incomplete [23]. Cytotrophoblast invasion of the spiral arteries is adequate only to the superficial decidua and does not reach the myometrium [24]. This reduced uteroplacental perfusion, which develops as a result of abnormal cytotrophoblast invasion of spiral arterioles, triggers the cascade of events leading to the maternal disorder. Placental ischemia causes the release of soluble placental factors, many of which are classified as anti-angiogenic or pro-inflammatory [25]. The endothelial dysfunction in its turn leads to hypertension, proteinuria and nondependent edema which are the characteristic clinical manifestations of PE [26].

\section{Biomarkers}

During the last decades, a lot of biochemical markers have been investigated based on pathophysiological observations of PE. In this review, the most important new biochemical markers for the prediction of $\mathrm{PE}$ which are responsible for placental dysfunction, inflammatory response and activation of the coagulation system are presented (Table 1).

\begin{tabular}{|c|c|c|c|}
\hline Markers & Features & Origin/expression & $\begin{array}{l}\text { Alteration in } \\
\mathrm{PE}\end{array}$ \\
\hline \multirow{2}{*}{$\begin{array}{l}\text { PIGF, VEGF, } \\
\text { sVEGFR-1(SFI } \\
\text { t-1) }\end{array}$} & \multirow[b]{2}{*}{$\begin{array}{l}\text { Markers } \\
\text { angiogenesis }\end{array}$} & \multirow[b]{2}{*}{ trofoblast } & $\wedge(\mathrm{sFlt}-1)$ \\
\hline & & & $\begin{array}{l}\text { v(VEGF, } \\
\text { PIGF) }\end{array}$ \\
\hline sEndoglin & $\begin{array}{l}\text { Receptor } \\
\text { TEGF } \beta 1 \& \beta 3 \quad \text { of }\end{array}$ & trophoblast & $\wedge$ \\
\hline
\end{tabular}

\begin{tabular}{|c|c|c|c|}
\hline TPO & $\begin{array}{l}\text { Cytokine for } \\
\text { thrombopoiesis }\end{array}$ & liver & $\wedge$ \\
\hline P-selectin & $\begin{array}{l}\text { Inflammation } \\
\text { reactions }\end{array}$ & $\begin{array}{l}\text { Platelets, endothelial } \\
\text { cells }\end{array}$ & $\wedge$ \\
\hline PP13 & $\begin{array}{l}\text { placental } \\
\text { implantation, } \\
\text { maternal vascular } \\
\text { remodeling }\end{array}$ & Syncytotrophoblast, & $\mathrm{v}$ \\
\hline \multirow{2}{*}{ PAPP-A } & \multirow{2}{*}{$\begin{array}{l}\text { Insulin -like growth } \\
\text { factor binding } \\
\text { protein }\end{array}$} & \multirow{2}{*}{ throphoblast } & $v$ initially \\
\hline & & & $\wedge>$ onset $\mathrm{PE}$ \\
\hline ADMA & $\begin{array}{l}\text { Inhibitor of NO } \\
\text { composition }\end{array}$ & $\begin{array}{l}\text { ADMA is formed by } \\
\text { methylation of } L \text {-arginine }\end{array}$ & $\wedge$ \\
\hline \multirow{2}{*}{ CRF\&CRF-BP } & \multirow{2}{*}{$\begin{array}{l}\text { Modulation } \\
\text { vascular tone }\end{array}$} & \multirow{2}{*}{ trophoblast } & $\wedge(\mathrm{CRF})$ \\
\hline & & & $\mathrm{v}$ (CRF-BP) \\
\hline \multirow[b]{2}{*}{$\mathrm{PGH}$} & \multirow{2}{*}{$\begin{array}{l}\text { Metabolism in } \\
\text { pregnancy }\end{array}$} & \multirow{2}{*}{$\begin{array}{l}\text { Syncytotrophoblast, } \\
\text { extravillus } \\
\text { cytotrophoblast }\end{array}$} & $v>$ onset $\mathrm{PE}$ \\
\hline & & & $\begin{array}{l}\wedge \text { before the } \\
\text { onset }\end{array}$ \\
\hline IGF1, IGFBP1 & implantation & placenta & $\begin{array}{l}v \quad(2 n d \\
\text { trimester) }\end{array}$ \\
\hline Inhibin A \& & \multirow{2}{*}{ TEGF $\beta$-family } & \multirow{2}{*}{ placenta } & \multirow{2}{*}{$\wedge$} \\
\hline Activin A & & & \\
\hline
\end{tabular}

Table 1: Biochemical markers for PE prediction; VEGF :vascular endothelial growth factor, PIGF: placental growth factor, sFlt1: soluble membrane -bound fms-like tyrosine kinase 1, sEng: Soluble endoglin, TPO: Thrombopoietin, PP13: Placenta protein 13, PAPP-A: Pregnancy -associated plasma protein, ADMA: Asymetric dimethylarginine, CRF-BP: Corticotropin releasing factor -binding protein, CRF: Corticotrophin-releasing factor, PGH: Placental growth hormone, IGF-1: Insulin like growth factor-1, IGFBP1: Insulin like growth factor binding protein-1

\section{Angiogenic Factors}

As a response to hypoxia, placenta produces pathogenic factors, which enter the maternal blood stream and are responsible for the endothelial dysfunction and other clinical manifestations of the disease including hypertension and proteinuria [26]. One of the most intensely studied pathways in the manifestation of PE is that which is related to vascular endothelial growth factor signalling [17,27]. Among the various angiogenic factors expressed by the placenta, vascular endothelial growth factor (VEGF) and placental growth factor (PIGF) play a very important role $[17,28]$. Angiogenic molecules such as VEGF, PIGF, and antiagiogenic molecules such as soluble membrane bound fms-like tyrosine kinase 1( sFlt1) may be important regulators of early placental development and pseudovasculogenesis. In fact, it has been shown that exogenous sFlt1 inhibits placental cytotrophoblast invasion in vitro [29].

VEGF is a potent angiogenic protein which promotes vasodilatation by inducing nitric oxide and prostacyclin synthesis by endothelial cells [30]. The function of VEGF is to promote susteinance, migration and differentiation of endothelial cells and vascular permeability [31]. It acts through two receptors tyrosine kinases, VEGF receptor-1(fms-like tyrosine kinase) and VEGF receptor-2, which are selectively expressed 
on the vascular endothelial cell surface. The VEGF receptor -1 has 2 isoforms: a transmembrane isoform and a soluble isoform (sFlt) [32].

PIGF is an angiogenic growth factor that amplifies VEGF signalling by displacing VEGF from the Flt-1 receptor and allows it to bind to the more active kinase-insert domain receptor [33]. Increased sFlt-1 during preeclampsia is associated with decreased free VEGF and free PIGF in the blood (25). The major source of PGIF is placental trophoblast, and it is expressed as several different isoforms which bind only to VEGF receptor 1 (VEGFR1) [34].

Inappropriate modification of maternal uterine spiral arteries results in increased production of sFlt-1. sFLt-1 is a circulating soluble receptor for both VEGF and free PIGF. Increased sFlt-1 levels in maternal plasma lead to less circulating free VEGF and free PIGF, thus preventing their availability to stimulate angiogenesis and maintain endothelial integrity [35]. sFlt-1 antagonizes the pro angiogenetic factors VEGF and PIGF by adhering to the receptor binding domains of VEGF and PIGF [36]. In the kidney this inactivation of free VEGF is believed to cause endotheliosis and proteinuria [35]. Abnormal expression of an endogenous sFlt-1 has been shown to be involved in PE cases [37].

Several studies have shown a decrease in serum levels of VEGF and PIGF with simultaneous increased levels of sFlt-1 in preeclamptic compared to normal pregnant women [36,38-40]. Inhibition of proangiogenic factors by increased levels of sFlt-1 leads to endothelial dysfunction which can be restored in vitro by exogenous PIGF and VEGF.

Maternal blood levels of sFlt-1 are related to the severity of preeclampsia. In an opposite manner the levels of bioactive VEGF and PIGF are significantly decreased in patients with severe symptoms, compared to normal pregnant woman or women with mild PE $[35,38,41]$. The sFlt-1/PIGF ratio has been reported as a better index for the angiogenic activity and can be used as a screening test for early onset preeclampsia [42].

\section{Soluble Endogline}

Soluble endoglin (sEng) is another antiogenetic factor, which acts together with sFlt-1 to induce a severe preeclamptic syndrome. Endoglin is a co-receptor for transforming growth factor (TGF)- $\beta 1$ and TGF- $\beta 3$ that is highly expressed on cellular membranes of the vascular endothelium and on syncytiotrophoblast [43,44]. It is involved in the angiogenesis and the regulation of the vascular tone [45]. Soluble endoglin (sEng) is a circulatory form of endoglin which consists of the extra cellular part of the molecule that may be produced through the proteocleavage of the placental membrane bound form. It acts as a potential anti-angiogenic factor by interfering with the binding of TGF- $\beta 1$ to its receptors, which ultimately affects the production of nitric oxide (NO), vasidilation and capillary formation by endothelial cells $[45,46]$.

Similar to levels of sFlt-1, sEng levels are high among women with PE. Women with preeclampsia have elevated sEng (4-fold higher) in the third trimester with levels rising 4-5 weeks prior to clinical diagnosis [47]. sEng is significantly increased in women who will develop PE by 9-14 weeks [48], while effective prediction can be achieved at 11-13 wk gestation [49].

The measurements of both sEng and sFLT-1 may be a better predictor of preeclampsia. Combined analysis of sEng and sFlt1 is able to predict early-onset preeclampsia with a sensitivity of $100 \%$ and a specificity of $93.3 \%$ [50]. The sFlt-1/PIGF ratio and more specifically (sFlt-1 + sEng)/PIGF ratio is a better predictor of PE than the individual markers [51].

\section{Thrombopoeitin}

Thrombopoietin (TPO) is a major cytokine for megakaryocytopoiesis and thrombopoiesis, and also plays an important role in the regulation of early hematopoiesis. TPO is a 94 $\mathrm{KD}$ protein primarily made in the liver and secreted into the circulation, while there is no storage form. TPO activates a number of signal pathways to exert its biological function by binding to its receptor (c-mpl). Most of the circulating TPO is cleared by platelets (and possibly megakaryocytes) by binding to the TPO receptor, followed by internalization and catabolism of the bound ligand [52]. Therefore the circulating TPO level is inversely related to the rate of platelet production. When platelet production is low, less TPO is cleared and its levels rise, whereas when platelet production is elevated, more TPO is cleared and its levels fall [53].

In 1998 Frolich et al. reported for first time that TPO levels were significantly greater in pregnancies complicated by the hemolysis, elevated liver enzymes and low platelets syndrome (HELLP)[54]. Moreover, it has been found that infants with thrombocytopenia associated with preeclampsia have increased circulating levels of TPO[55]. On the contrary, Albert et al. found that preterm infants born to women with preeclampsia $(n=11)$ had lower TPO levels than NTP infants with a similar gestation age $(<41 \mathrm{pg} / \mathrm{ml}$ vs $95 \mathrm{pg} / \mathrm{ml})$ [56].In addition lack of TPO potentiation of platelet collagen activation in the first trimester has been associated with preeclampsia [57].

\section{P-selectin}

P-selectin is a member of the selectin family of cell surface adhesion molecules. It is expressed by platelets and endothelial cells upon activation and it is involved in leucocyte-endothelial interactions. Its role is crucial in inflammatory reactions by supporting the recruitment and activation of circulating leucocytes $[51,58]$.

During pregnancy, maternal P-selectin expression occurs exclusively at the implantation site and may provide a mechanism for maternal and fetal cell interaction to enable the trophoblast to implant within the uteroplacental vessel lumen [59]. P-selectin is released from the cell surface and circulates as a soluble molecule in the maternal plasma [60]. Both the membrane form and the soluble form of Pselectin are agonists of the processes of thrombosis and inflammation [61]. As PE is associated with extensive platelet activation, increased pselectin expression may play an important role in the pathophysiology of the disease [62].

In a study by Laskowska $\mathrm{M}$ et al. it was found that elevated levels of soluble P-selectin are associated with $\mathrm{PE}$. This may confirm the presence of platelet and endothelial activation, which may be due to the systemic inflammatory response in this serious pregnancy disorder [63].

Aksoy et al. suggested that P-selectin may be an additional risk marker for PE, and may be useful in distinguishing women with mild or severe PE and normal pregnancy [64].

In another study Bosio et al. supported an inflammatory model for $\mathrm{PE}$, in which endothelial cell activation may be secondary to a primary 
inflammatory response. In this study, plasma P-selectin had significant potential as a first trimester clinical marker of PE [65].

Last, Holmes et al. showed that P-selectin concentration is significantly higher in the second and third trimester of pregnancy when compared to non-pregnant controls [66].

\section{Placenta Protein 13}

Placenta protein 13 (PP13) is a small protein $(32 \mathrm{kD})$ which is produced by the placenta, specifically the syncytiotrophoblast. It binds to protein on the extracellular matrix between the placenta and the endometrium and is thought to be involved in placental implantation and maternal vascular remodeling $[67,68]$.

Recently this protein has been attracted as a potential marker for early diagnosis of PE [69]. The PP13 serum levels slowly increase during a normal pregnancy. Decreased levels of PP-13 have been found in patients who developed PE, particularly in cases with early onset disease [70]. In a study by Nicolaides et al. in patients with severe PE who gave birth before 34 weeks, the PP13 serum levels were lower than in the normotensive individuals. They suggested that effective screening for PE requiring delivery before 34 weeks can potentially be provided by assessment of a combination of maternal serum PP-13 and uterine artery Doppler in the first trimester of pregnancy [71]. Another study, analyzed maternal serum PP-13 levels at 9-12 weeks gestation and found lower levels in women who went on to develop preeclampsia compared with controls [72].

Romero et al. concluded that maternal serum first-trimester PP13 appears to be a reasonable marker for risk assessment for preterm preeclampsia, but a weak marker for severe $\mathrm{PE}$ at term and ineffective for identifying mild preeclampsia at term [73].

\section{Pregnancy -Associated Plasma Protein (PAPP-A)}

PAPP-A (pregnancy-associated plasma protein A) is a disulfide bond linked homodimeric peptidase of 1628 amino acids and a mass of $400 \mathrm{KDA}$ produced by growing trophoblast which indirectly induces aggression to the endometrium [74]. It is an insulin- like growth factor binding protein (IGFBP) protease with specificity for IGFBR 2 and 4. Reduced levels of PAPP-A may result in increased amounts of insulin-like growth factor (IGF) being bound to its carrier proteins and hence not available at the cell receptor level to stimulate fetal growth and tophoblast invasion of the desidua [75]. Decreased levels of PAPP-A are associated with a higher risk of PE, but its predictive value is not as precise as $\mathrm{PP} 13$ and Doppler ultrasonography [76]. Decreased PAPP-A levels, are seen in all trimesters in women with $\mathrm{PE}$ [77]. It is not clear whether early evaluation of risk factors using PP13 and PAPP-A, alone or in combination, can improve pregnancy outcome [78]. The predictive values of placental function markers such as PP13 and PAPP-A in the second trimester has not been clearly defined and there is controversy among studies [79].

Moslemi Zadeh et al. suggested that it is possible to increase the predictive value of each test by combining the measurements of PAPP$A$ and PP13 in the first and second trimester [80].

Poon et al. showed that the PAPP-A serum levels in the first trimester was under the fifth percentage in $21.9 \%$ and $6.5 \%$ of patients with early and late PE, respectively. They noted that the PAPP-Arelated patient-specific risk for $\mathrm{PE}$ can be modified by the measurement of uterine arteries Doppler PI (UtA-PI) [81].
D' Anna et al. also concluded that the first trimester PAPP-A is not useful in predicting late onset $\mathrm{PE}$, as the levels of PAPP-A were significantly reduced only in the early onset $\mathrm{PE}$, while the levels of PAPP-A in late onset preeclampsia did not differ from that of controls [82].

\section{Asymetric Dimethylarginine (ADMA)}

ADMA (asymmetric dimethylarginine) is an antiangiogenetic factor that decreases VEGF expression in endothelial cells and prevents the formation of nitric oxide (NO) from nitric oxide synthases (NOS) [83]. Through the action of protein arginine-N-methyltransferases, Larginine can be methylated to form asymmetric dimethylarginine (ADMA) [84].

Elevated levels of ADMA have been implicated in the pathophysiology of other microvascular diseases and are a prognostic marker for major cardiovascular events and mortality in patients with established cardiovascular disease as well as in the general population [85]. Increased ADMA levels in endothelium-dependent vascular dysfunction were also detected in diabetic, hypertensive, and hypercholesterolemic patients [86-88]. ADMA levels may decrease at the beginning of a normal pregnancy [89] but its concentration increases significantly in $\mathrm{PE}$ as it has been reported in several studies [90-92]. Several studies have reported elevated ADMA levels in PE. It seems that ADMA is involved in the pathogenesis of $\mathrm{PE}$ as it inhibits the NO synthesis in rodents during pregnancy and produces signs similar to that of preeclampsia $[93,94]$.

\section{Corticotrophin-Releasing Factor (CRF), Corticotropin Releasing Factor-Binding Protein (CRF-BP)}

In pregnancy, CRF (corticotropin-releasing factor) has a paracrine action inducing placental adrenocorticotropin hormone (ACTH) release, as well as an endocrine function modulating fetal pituitaryadrenal cortex axis $[95,96]$. Corticotropin-releasing factor-binding protein (CRF-BP) is a $37-\mathrm{kDa}$ protein of 322 amino acids, which is expressed in human trophoblast and intrauterine tissues during pregnancy [97]. It modulates the activity of the hypothalamuspituitary-adrenal axis during pregnancy, counteracting the actions of circulating or locally acting CRF [98]. Petraglia et al. showed an inverse correlation between reduced plasma CRF-BP levels and increased CRF levels in the maternal circulation of patients with pregnancy-induced hypertension. They also showed that these hormonal changes did not occur before the onset of disease, suggesting that the measurement of these polypeptides in maternal plasma does not predict the development of hypertension [99]. Florio et al. measured maternal plasma concentrations of two placental neurohormones, corticotropin-releasing factor (CRF) and CRFbinding protein (CRF-BP), in 58 at-risk pregnant women consecutively enrolled between 28 and 29 weeks to evaluate whether their assessment may predict third trimester-onset preeclampsia. CRF and CRF-BP levels were significantly higher and lower, respectively, in the patients who later developed PE [100].

\section{Placental Growth Hormone (PGH)}

Placental growth hormone (PGH) is a pregnancy-specific hormone that has been proposed to play a role in trophoblast invasion [101] and fetal growth [102], as well as maternal adaptation to pregnancy [103]. It is expressed by syncytiotrophoblast and extravillous cytotrophoblast [104]. PGH can be detected in maternal blood at as early as 5 weeks of 
gestation [105] and increases throughout pregnancy until term at which time its concentration may remain stable or slightly decrease $[106,107]$.

Sifakis et al. investigated whether maternal PGH serum concentration at 11-13 weeks' gestation, is altered in pregnancies that deliver small for gestational age (SGA) neonates. They found that maternal serum PGH at 11-13 weeks' gestation is unlikely to be a useful biochemical marker for early prediction of SGA. Moreover, they observed that $\mathrm{PGH}$ level is normal during the first trimester in pregnancies that subsequently developed $\mathrm{PE}$, suggesting that this hormone is unlikely to play a role in the pathogenesis of the disease [108].

Mittal et al. tried to determine whether maternal serum concentrations are different in women with $\mathrm{PE}$, women with $\mathrm{PE}$ who deliver a small for gestational age neonate (PE + SGA), and those with SGA alone. They concluded that $\mathrm{PE}$ is associated with higher median concentrations in both the maternal and the fetal circulation compared to normal pregnancies. Patients with PE + SGA had lower concentrations than preeclamptic patients without SGA. They suggested that may play a role in the pathogenesis of $\mathrm{PE}$ as well as of fetal growth restriction [109].

\section{Insulin like Growth Factors (IGFs)}

Insulin-like growth factor-I (IGF-I) is a strong mitogen that promotes cell proliferation and differentiation and has a critical role in many aspects of placental development and regulation of fetal and postnatal growth [110]. It increases the differentiation of cytotrophoblasts into syncytiotrophoblast and extravillous trophoblasts. Moreover, it increases the proliferation of placental fibroblast and trophoblasts and it enhances the trophoblast invasion [111]. The actions of IGF-1 in the circulation and the extracellular matrix are modulated by the presence of the IGF-binding proteins (IGFBP), mainly 1 and 3 (IGFBP-1 and IGFBP-3). Insulin-like growth factor I and II regulate the life cycle of trophoblast in the developing human placenta [111]. In the non-pregnant state, IGFBP-1 is produced in the liver and it is strongly regulated by insulin. In pregnancy, IGFBP-1 is also produced by the placenta, resulting in higher maternal concentrations of this protein [112]. IGFBP-3 is the most abundant IGFBP in the circulation, while both IGFBP-1 and -3 prolong IGF half-life in plasma and provide an IGF reservoir for target tissues [113]. Sifakis et al. reported that in pregnancies destined to develop PE the circulating levels of IGF-I and IGFBP-1 are already decreased from the first-trimester of pregnancy [114,115]. The IGFBP-3 levels are increased in women who will develop late- but not early-onset PE. Finally, the absence of significant association between serum IGF-I, IGFBP-1 and IGFBP-3 and uterine artery Doppler PI, suggests that the possible implication in the pathogenesis of $\mathrm{PE}$ is mediated by a mechanism unrelated to impaired placental perfusion [116].

\section{Inhibin A, Activin A}

Inhibin A and Activin A are glycoproteins, members of the transforming growth factor $\mathrm{b}$ family, and during pregnancy, are largely released by the placenta. Term placental cells secrete increased levels of inhibin $\mathrm{A}$ and activin $\mathrm{A}$ in the presence of inflammatory cytokines( increased in pre-eclampsia) which are potent stimulators of inhibin A and activin A [117]. In normal pregnancy, concentrations of both hormones rise in the third trimester, and levels have been shown to be elevated approximately 10 -fold in the women with established preeclampsia [118].Serum levels can be raised as early as 10-15 weeks of pregnancy in women who subsequently develop pre-eclampsia compared with gestational age-matched control pregnant women [119]. Second trimester levels of inhibin A have been shown to be elevated in both serum and amniotic fluid [120] in women who went on to develop severe preeclampsia.The second trimester levels of both inhibin $\mathrm{A}$ and activin $\mathrm{A}$ have been reported to add significant prognostic information when measured in women with abnormal uterine artery Doppler studies [121]. On the contrary Davidson et al. in second trimester serum samples of 39 women who subsequently developed preeclampsia found significantly elevated Activin A levels but not elevated inhibin A levels [122].

\section{Combination of Markers}

Many investigators attempted to improve the predictive value by combining different maternal serum biomarkers with clinical characteristics and Doppler ultrasonography. The use of multiple markers increases the specificity and sensitivity of the screening possibly because they reflect different pathways to the disease process. Spencer et al. investigated the potential value of the combination of uterine artery Dopplers and the measurement of maternal serum pregnancy-associated plasma protein-A (PAPP-A), free $\beta$-human chorionic gonadotropin ( $\beta$-hCG), activin $A$ and inhibin $A$ at $22+0$ to $24+6$ weeks' gestation. These maternal serum markers were measured in samples obtained from women with singleton pregnancies who participated in a screening study for pre-eclampsia by transvaginal color flow Doppler measurement of the uterine artery pulsatility index (PI). A search was made of the database to identify those who subsequently developed preeclampsia $(\mathrm{n}=24)$ and a group of controls with normal outcome $(\mathrm{n}=144)$. They suggested that in the PE group, compared with controls, the uterine artery mean PI and the maternal serum levels of PAPP-A, free $\beta$-hCG, activin A and inhibin A were significantly increased. The detection rates of $\mathrm{PE}$, for a false positive rate of $5 \%$, was $50 \%$ by uterine artery mean PI, $5 \%$ by PAPP-A, $10 \%$ by free $\beta$-hCG, $35 \%$ by inhibin A and $44 \%$ by activin A. Screening by a combination of uterine artery mean PI and maternal serum activin A and inhibin A could detect $75 \%$ and $92 \%$ of patients who subsequently developed pre-eclampsia, for a false positive rate of $5 \%$ and $10 \%$, respectively [123]. Wald et al. in a nested case control study that carried out on 96 women with preeclampsia and 5 controls for each case, added a screening process for PE to an existing Down syndrome screening programme using the quadruple test markers (AFP, uE (3), hCG (total or free beta) and inhibin-A) they could detected over $40 \%$ of pregnancies with $\mathrm{PE}$ at an acceptable false-positive rate of $6 \%$ and with minimal additional cost [124].

Spencer et al. in a nested case control study of PE that carried out on 446 controls and 44 cases with early PE where delivery was induced prior to 35 weeks and a further 44 cases with PE in which delivery was not induced before term, observed that first trimester PP-13 levels may be useful in predicting $\mathrm{PE}$ and early-onset $\mathrm{PE}$, and the accuracy of the method increases when coupled with second-trimester uterine arteries Doppler PI measurement. Moreover, first-trimester PAPP-A provided some prediction for $\mathrm{PE}$ when used in combination with uterine arteries Doppler PI, but did not add to the prediction of early-onset PE when PP-13 and uterine arteries Doppler PI were used together [125]. Nicolaides et al. investigated the value of maternal serum placental protein 13 (PP-13) measurements and uterine artery Doppler during first-trimester screening in the prediction of early pre-eclampsia. They carried out a nested case control prospective study of pregnancies at 
$11+0$ to $13+6$ weeks of gestation. In the cases that developed preeclampsia requiring delivery before 34 weeks, compared with the unaffected pregnancies, the median uterine artery PI was higher $(1.43$ $\mathrm{MoM})$ and the median serum PP-13 level was lower $(0.07$ MoM; $\mathrm{P}<$ 0.001). This model predicted that for a $90 \%$ detection rate of preeclampsia requiring delivery before 34 weeks, the false-positive rate of screening by PP- 13 was $12 \%$, by uterine artery PI was $31 \%$ and by a combination of the two methods was $9 \%$. A policy of contingency screening, whereby all women are screened by maternal serum PP-13 and only the $14 \%$ at highest risk are then screened by Doppler, achieved a detection rate of $90 \%$ with an overall false-positive rate of $6 \%$.They suggested that effective screening for severe PE requiring delivery before 34 weeks, could potentially be provided by assessment of a combination of maternal serum PP-13 and uterine arteries Doppler in the first trimester of pregnancy [126]. Poon et al. tried to establish a method of screening for pregnancy hypertension by a combination of maternal variables, including mean arterial pressure, uterine artery pulsatility index, pregnancy-associated plasma proteinA, and placental growth factor in early pregnancy. The base-cohort population constituted of 7797 singleton pregnancies, including 34 case subjects who developed preeclampsia (PE) requiring delivery before 34 weeks (early PE) and 123 with late PE, 136 with gestational hypertension, and 7504 cases subjects $(96.3 \%)$ who were unaffected by $\mathrm{PE}$ or gestational hypertension. Logistic regression analysis was used to derive algorithms for the prediction of hypertensive disorders. They estimated that with the algorithm for early PE, 93.1\%, 35.7\%, and $18.3 \%$ of early $\mathrm{PE}$, late $\mathrm{PE}$, and gestational hypertension, respectively, could be detected with a $5 \%$ false-positive rate and that 1 in 5 pregnancies classified as being screen positive would develop pregnancy hypertension [127]. Akolekar et al. investigated the potential value of maternal plasma inhibin $\mathrm{A}$ in the first-trimester screening for PE. The concentration of inhibin A at 11-13 weeks was measured in samples from 121 pregnancies that developed PE, 87 cases of gestational hypertension (GH) and 208 normal controls The authors found that the combination of maternal factors, plasma inhibin A and uterine arteries Doppler PI had a detection rate for early and late PE of $88 \%$ and $42 \%$, respectively, for a false positive rate of $10 \%$ [128]. Last ,in another study the concentration of PlGF at $11+0$ to $13+6$ weeks' gestation was measured in samples from 127 pregnancies that developed PE, including 29 that required delivery before 34 weeks (early PE) and 98 with late PE, 88 cases of gestational hypertension $(\mathrm{GH})$ and 609 normal controls. In this study by combining maternal characteristics (maternal weight, cigarette smoking racial origin), obstetric history, serum PlGF and uterine arteries Doppler PI, the detection rate for early- and late-onset PE were $90 \%$ and $49 \%$, respectively, for a false-positive rate of $10 \%$ [129].

\section{Conclusion}

The biochemical markers are not effective when they are used alone for the prediction of PE. The combination of these markers with other predictors such as maternal history, clinical features, risk factors, demographic characteristics, Doppler velocimetry will develop more effective models.

The identification of first trimester markers will contribute to a better understanding of the pathophysiology of PE and will give us a clinically validated screening procedure for a better management of this disorder. In addition the early identification of high-risk cases will offer the opportunity for prophylactic therapy, thus improving the perinatal outcome.
Recently published data suggest that studies on metabolomics, proteomics, fetal free DNA/RNA and other new techniques which aim to generate new predictive markers of $\mathrm{PE}$, are promising prognostic tools of PE. PE is a multifactorial disorder. Therefore there is a need for large scale multicenter studies including women with different demographic characteristic and different risk of developing the syndrome in order to have a significant predictive model for a routine use in clinical settings. The goal for future studies will be to identify the best combination of markers that would result in optimal screening prediction for PE.

\section{References}

1. Hauth JC, Ewell MG, Levine RJ, Esterlitz JR, Sibai B, et al. (2000) Pregnancy outcomes in healthy nulliparas who developed hypertension. Calcium for Preeclampsia Prevention Study Group. Obstet Gynecol 95: 24-28.

2. Powe CE, Levine RJ, Karumanchi SA (2011) Preeclampsia, a disease of the maternal endothelium: the role of antiangiogenic factors and implications for later cardiovascular disease. Circulation 123: 2856-2869.

3. Vikse BE (2013) Pre-eclampsia and the risk of kidney disease. Lancet 382: 104-106.

4. Harder T, Rodekamp E, Schellong K, Dudenhausen JW, Plagemann A (2007) Birth weight and subsequent risk of type 2 diabetes: a metaanalysis. Am J Epidemiol 165: 849-857.

5. Sibai B, Dekker G, Kupferminc M (2005) Pre-eclampsia. Lancet 365: 785-799.

6. World Health Organization (2005) World Health report. Make every mother and Child Count. Geneva: World Health Org.

7. Altman D, Carroli G, Duley L, Farrell B, Moodley J, et al. (2002) Magpie Trial Collaboration Group. Do women with pre-eclampsia, and their babies, benefit from magnesium sulphate? The Magpie Trial: a randomized placebo-controlled trial. Lancet 359: 1877-1890.

8. Zhong Y, Tuuli M, Odibo AO (2010) First-trimester assessment of placenta function and the prediction of preeclampsia and intrauterine growth restriction. Prenat Diagn 30: 293-308.

9. Emonts P, Seaksan S, Seidel L, Thoumsin H, Gaspard U, et al. (2008) Prediction of maternal predisposition to preeclampsia. Hypertens Pregnancy 27: 237-245.

10. England LJ, Levine RJ, Qian C, Morris CD, Sibai BM, et al. (2002) Smoking before pregnancy and risk of gestational hypertension and preeclampsia. Am J Obstet Gynecol 186: 1035-1040.

11. Onwudiwe N, Yu CK, Poon LC, Spiliopoulos I, Nicolaides KH (2008) Prediction of pre-eclampsia by a combination of maternal history, uterine artery Doppler and mean arterial pressure. Ultrasound Obstet Gynecol 32: 877-883.

12. ACOG Committee on Practice Bulletins--Obstetrics (2002) ACOG practice bulletin. Diagnosis and management of preeclampsia and eclampsia. Number 33, January 2002. Obstet Gynecol 99: 159-167.

13. Carr DB, Epplein M, Johnson CO, Easterling TR, Critchlow CW (2005) A sister's risk: family history as a predictor of preeclampsia. Am J Obstet Gynecol 193: 965-972.

14. Esplin MS, Fausett MB, Fraser A, Kerber R, Mineau G, et al. (2001) Paternal and maternal components of the predisposition to preeclampsia. N Engl J Med 344: 867-872.

15. Wang A, Rana S, Karumanchi SA (2009) Preeclampsia: the role of angiogenic factors in its pathogenesis. Physiology (Bethesda) 24: 147-158.

16. Farag K, Hassan I, Ledger WL (2004) Prediction of preeclampsia: can it be achieved? Obstet Gynecol Surv 59: 464-482.

17. Antsaklis A, Daskalakis G, Tzortzis E, Michalas S (2000) The effect of gestational age and placental location on the prediction of pre-eclampsia by uterine artery Doppler velocimetry in low-risk nulliparous women. Ultrasound Obstet Gynecol 16: 635-639. 
18. Spencer K, Cowans NJ, Nicolaides KH (2008) Low levels of maternal serum PAPP-A in the first trimester and the risk of pre-eclampsia. Prenat Diagn 28: 7-10.

19. Poon LC, Kametas NA, Chelemen T, Leal A, Nicolaides KH (2010) Maternal risk factors for hypertensive disorders in pregnancy: a multivariate approach. J Hum Hypertens 24: 104-110.

20. Chaiworapongsa T, Chaemsaithong P, Yeo L, Romero R (2014) Preeclampsia part 1: current understanding of its pathophysiology. Nat Rev Nephrol 10: 466-480.

21. Pratt A, Da Silva Costa F, Borg AJ, Kalionis B, Keogh R, et al. (2014) Placenta-derived angiogenic proteins and their contribution to the pathogenesis of preeclampsia. Angiogenesis.

22. Schaaps JP, Tsatsaris V, Goffin F, Brichant JF, Delbecque K, et al. (2005) Shunting the intervillous space: new concepts in human uteroplacental vascularization. Am J Obstet Gynecol 192: 323-332.

23. Zhou Y, Damsky CH, Fisher SJ (1997) Preeclampsia is associated with failure of human cytotrophoblasts to mimic a vascular adhesion phenotype. One cause of defective endovascular invasion in this syndrome? J Clin Invest 99: 2152-2164.

24. Meekins JW, Pijnenborg R, Hanssens M, McFadyen IR, van Asshe A (1994) A study of placental bed spiral arteries and trophoblast invasion in normal and severe pre-eclamptic pregnancies. Br J Obstet Gynaecol 101: 669-674.

25. Lam C, Lim KH, Karumanchi SA (2005) Circulating angiogenic factors in the pathogenesis and prediction of preeclampsia. Hypertension 46: 1077-1085.

26. Palei AC, Spradley FT, Warrington JP, George EM, Granger JP (2013) Pathophysiology of hypertension in pre-eclampsia: a lesson in integrative physiology. Acta Physiol (Oxf) 208: 224-233.

27. LaMarca BD, Alexander BT, Gilbert JS, Ryan MJ, Sedeek M, et al. (2008) Pathophysiology of hypertension in response to placental ischemia during pregnancy: a central role for endothelin? Gend Med 5 Suppl A: S133-138

28. Gilbert JS, Ryan MJ, LaMarca BB, Sedeek M, Murphy SR, et al. (2008) Pathophysiology of hypertension during preeclampsia: linking placental ischemia with endothelial dysfunction. Am J Physiol Heart Circ Physiol 294: H541-550.

29. McMahon K, Karumanchi SA2, Stillman IE3, Cummings P1, Patton D1, et al. (2014) Does soluble fms-like tyrosine kinase-1 regulate placental invasion? Insight from the invasive placenta. Am J Obstet Gynecol 210: 68.

30. Saha T, Halder M, Das A, Das SK (2013) Role of nitric oxide, angiogenic growth factors and biochemical analysis in preeclampsia. Indian J Biochem Biophys 50: 462-466.

31. Nagy JA, Vasile E, Feng D, Sundberg C, Brown LF, et al. (2002) Vascular permeability factor/vascular endothelial growth factor induces lymphangiogenesis as well as angiogenesis. J Exp Med 196: 1497-1506.

32. Vempati P, Popel AS, Mac Gabhann F (2014) Extracellular regulation of VEGF: isoforms, proteolysis, and vascular patterning. Cytokine Growth Factor Rev 25: 1-19.

33. Vitoratos N, Hassiakos D, Iavazzo C (2012) Molecular mechanisms of preeclampsia. J Pregnancy 2012: 298343.

34. Desai J, Holt-Shore V, Torry RJ, Caudle MR, Torry DS (1999) Signa transduction and biological function of placenta growth factor in primary human trophoblast. Biol Reprod 60: 887-892.

35. Maynard SE, Min JY, Merchan J, Lim KH, Li J, et al. (2003) Excess placental soluble fms-like tyrosine kinase 1 (sFlt1) may contribute to endothelial dysfunction, hypertension, and proteinuria in preeclampsia. J Clin Invest 111: 649-658.

36. Masoura S, Kalogiannidis I, Makedou K, Theodoridis T, Koiou Ket al. (2014) Biomarkers of endothelial dysfunction in preeclampsia and neonatal morbidity: a case-control study. Eur J Obstet Gynecol Reprod Biol 175: 119-123.

37. Tsatsaris V, Goffin F, Foidart JM (2004) Circulating angiogenic factors and preeclampsia. N Engl J Med 350: 2003-2004.
38. Chaiworapongsa T, Romero R, Espinoza J, Bujold E, Mee Kim Y, et al. (2004) Evidence supporting a role for blockade of the vascular endothelial growth factor system in the pathophysiology of preeclampsia. Young Investigator Award. Am J Obstet Gynecol 190: 1541-1547.

39. Chung JY, Song Y, Wang Y, Magness RR, Zheng J (2004) Differential expression of vascular endothelial growth factor (VEGF), endocrine gland derived-VEGF, and VEGF receptors in human placentas from normal and preeclamptic pregnancies. J Clin Endocrinol Metab 89: 2484-2490.

40. Levine RJ, Karumanchi SA (2005) Circulating angiogenic factors in preeclampsia. Clin Obstet Gynecol 48: 372-386.

41. Robinson CJ, Johnson DD, Chang EY, Armstrong DM, Wang W (2006) Evaluation of placenta growth factor and soluble Fms-like tyrosine kinase 1 receptor levels in mild and severe preeclampsia. Am J Obstet Gynecol 195: 255-259.

42. Petla LT, Chikkala R, Ratnakar KS, Kodati V, Sritharan V (2013) Biomarkers for the management of pre-eclampsia in pregnant women. Indian J Med Res 138: 60-67.

43. Wikström AK, Larsson A, Eriksson UJ, Nash P, Nordén-Lindeberg S, et al. (2007) Placental growth factor and soluble FMS-like tyrosine kinase-1 in early-onset and late-onset preeclampsia. Obstet Gynecol 109: 1368-1374.

44. Lorquet S, Berndt S, Blacher S, Gengoux E, Peulen O, et al. (2010) Soluble forms of VEGF receptor-1 and -2 promote vascular maturation via mural cell recruitment. FASEB J 24: 3782-3795.

45. Chen Y (2009) Novel angiogenic factors for predicting preeclampsia: sFlt-1, PlGF, and soluble endoglin. Open Clin Chem J 2: 1-6.

46. Nachtigal P, Zemankova Vecerova L, Rathouska J, Strasky Z (2012) The role of endoglin in atherosclerosis. Atherosclerosis 224: 4-11.

47. Venkatesha S, Toporsian M, Lam C, Hanai J, Mammoto T, et al. (2006) Soluble endoglin contributes to the pathogenesis of preeclampsia. Nat Med 12: 642-649.

48. Levine RJ, Lam C, Qian C, Yu KF, Maynard SE, et al. (2006) Soluble endoglin and other circulating antiangiogenic factors in preeclampsia. $\mathrm{N}$ Engl J Med 355: 992-1005.

49. Akolekar R, Syngelaki A, Sarquis R, Zvanca M, Nicolaides KH (2011) Prediction of early, intermediate and late pre-eclampsia from maternal factors, biophysical and biochemical markers at 11-13 weeks. Prenat Diagn 31: 66-74.

50. Stepan H, Geipel A, Schwarz F, Krämer T, Wessel N, et al. (2008) Circulatory soluble endoglin and its predictive value for preeclampsia in second-trimester pregnancies with abnormal uterine perfusion. Am J Obstet Gynecol 198 : e1-6.

51. Levine RJ, Maynard SE, Qian C, Lim KH, England LJ, et al. (2004) Circulating angiogenic factors and the risk of preeclampsia. N Engl J Med 350: 672-683.

52. Xiao B, Ye JY, Xu Y, Yang M (2013) [Molecular mechanism of thrombopoietin signal pathways and its new effects]. Zhongguo Shi Yan Xue Ye Xue Za Zhi 21: 254-257.

53. Emmons RV, Reid DM, Cohen RL, Meng G, Young NS, et al. (1996) Human thrombopoietin levels are high when thrombocytopenia is due to megakaryocyte deficiency and low when due to increased platelet destruction. Blood 87: 4068-4071.

54. Frölich MA, Datta S, Corn SB (1998) Thrombopoietin in normal pregnancy and preeclampsia. Am J Obstet Gynecol 179: 100-104.

55. Paul DA, Leef KH, Taylor S, McKenzie S (2002) Thrombopoietin in preterm infants: gestational age-dependent response. J Pediatr Hematol Oncol 24: 304-309.

56. Albert TS, Meng YG, Simms P, Cohen RL, Phibbs RH (2000) Thrombopoietin in the thrombocytopenic term and preterm newborn. Pediatrics 105: 1286-1291.

57. Carroll RC, Owers RL, Elder RF, Hennessey MD, Patteson SK, et al (2005) Lack of thrombopoietin potentiation of platelet collagen activation in the first trimester is associated with preeclampsia. Thromb Res 116: 51-54. 
58. André P (2004) P-selectin in haemostasis. Br J Haematol 126: 298-306.

59. Uszyaski M1, Uszy ^̊,ski W, Zekanowska E (2008) P-selectin in placenta and gestational myometrium: its measurements and hypothetical role in hemostasis of placental bed after labor. J Perinat Med 36: 213-216.

60. Wasiluk A (2004) Markers of platelets activation, CD 62P and soluble Pselectin in healthy term neonates. J Perinat Med 32: 514-515.

61. Burrows TD, King A, Loke YW (1994) Expression of adhesion molecules by endovascular trophoblast and decidual endothelial cells: implications for vascular invasion during implantation. Placenta. 15: 21-33.

62. Holthe MR, Staff AC, Berge LN, Lyberg T (2004) Different levels of platelet activation in preeclamptic, normotensive pregnant, and nonpregnant women. Am J Obstet Gynecol 190: 1128-1134.

63. Laskowska M, Laskowska K, Oleszczuk J (2013) Elevated maternal serum sP-selectin levels in preeclamptic pregnancies with and without intrauterine fetal growth restriction, but not in normotensive pregnancies complicated by isolated IUGR. Med Sci Monit 19: 118-124.

64. Aksoy H, Kumtepe Y, Akçay F, Yildirim AK (2002) Correlation of Pselectin and lipoprotein(a), and other lipid parameters in preeclampsia. Clin Exp Med 2: 39-43.

65. Bosio PM, Cannon S, McKenna PJ, O'Herlihy C, Conroy R, et al. (2001) Plasma P-selectin is elevated in the first trimester in women who subsequently develop pre-eclampsia. BJOG 108: 709-715.

66. Holmes VA, Wallace JM, Gilmore WS, McFaul P, Alexander HD (2002) Soluble P-selectin levels during normal pregnancy: a longitudinal study. BJOG 109: 997-1002.

67. Nicolaides KH, Bindra R, Turan OM, Chefetz I, Sammar M, et al. (2006) A novel approach to first-trimester screening for early pre-eclampsia combining serum PP-13 and Doppler ultrasound. Ultrasound Obstet Gynecol 27: 13-17.

68. Chafetz I, Kuhnreich I, Sammar M, Tal Y, Gibor Y, et al. (2007) Firsttrimester placental protein 13 screening for preeclampsia and intrauterine growth restriction. Am J Obstet Gynecol 197: e1-7.

69. Chaftez I, kuhnreich I, Smmar M (2007) First trimester Placental protein 13 screening for preeclampsia and intra uterine growth restriction. American Journal of Obstetrics and Gynecology 197: 35-37.

70. Huppertz B, Sammar M, Chefetz I, Neumaier-Wagner P, Bartz C, et al. (2008) Longitudinal determination of serum placental protein 13 during development of preeclampsia. Fetal Diagn Ther 24: 230-236.

71. Nicolaides KH, Bindra R, Turan OM, Chefetz I, Sammar M, et al. (2006) A novel approach to first-trimester screening for early pre-eclampsia combining serum PP-13 and Doppler ultrasound. Ultrasound Obstet Gynecol 27: 13-17.

72. Chafetz I, Kuhnreich I, Sammar M (2007) First-trimester placental protein 13 screening for preeclampsia and intrauterine growth restriction. Am J Obstet Gynecol 197: e1-e7.

73. Romero R, Kusanovic JP, Than NG, Erez O, Gotsch F, et al. (2008) Firsttrimester maternal serum PP13 in the risk assessment for preeclampsia. Am J Obstet Gynecol 199: 122.

74. Sekiya T, Kurahashi H, Udagaway Y, (2008) Increased level of pregnancy assouiated protein A2 in the serum of preeclam patients. Molecular Human Reproduction 14: 595-602.

75. Bale LK, Conover CA (2005) Disruption of insulin-like growth factor-II imprinting during embryonic development rescues the dwarf phenotype of mice null for pregnancy-associated plasma protein-A.J Endocrinol 186: 325-331.

76. Hertig A, Berkane N, Lefevre G (2004) Maternal serum sFlt1 concentration is an early and reliable predictive marker of preeclampsia. Clinical Chemistry 50: 1702-1703.

77. Spencer K, Cowans NJ, Chefetz I, Tal J, Meiri H (2007) First-trimester maternal serum PP-13, PAPP-A and second-trimester uterine artery Doppler pulsatility index as markers of pre-eclampsia. Ultrasound in Obstetrics and Gynecology 29: 128-134.

78. Heilmannl L, Seikmann U (1998) Hemodynamic and hemorhological profiles in women with proteinuric hypertension og pregnancy and in pregnant controls. Archives of Gynecology and Obstetrics 246: 159-168.
79. Costa SL, Proctor L, Dodd JM (2008) Screening for placental insufficiency in high-risk pregnancies: is earlier better? Placenta 29: 1034-1040.

80. Moslemi Zadeh N, Naghshvar F, Peyvandi S, Gheshlaghi P, Ehetshami S (2012) PP13 and PAPP-A in the First and Second Trimesters: Predictive Factors for Preeclampsia? ISRN Obstet Gynecol 2012: 263871.

81. Poon LC, Maiz N, Valencia C, Plasencia W, Nicolaides KH (2009) Firsttrimester maternal serum pregnancy-associated plasma protein-A and pre-eclampsia. Ultrasound Obstet Gynecol 33: 23-33.

82. D'Anna R, Baviera G, Giordano D, Russo S, Dugo N, et al. (2009) First trimester serum PAPP-A and NGAL in the prediction of late-onset preeclampsia. Prenat Diagn 29: 1066-1068.

83. Moncada S, Higgs A (1993) The L-arginine-nitric oxide pathway. N Engl J Med 329: 2002-2012.

84. Moonen RM, Huizing MJ, Cavallaro G, González-Luis GE, Bas-Suárez P, et al. (2014) Plasma levels of dimethylarginines in preterm very low birth weight neonates: its relation with perinatal factors and short-term outcome. Int J Mol Sci 16: 19-39.

85. Böger RH, Diemert A, Schwedhelm E, Lüneburg N, Maas R, et al. (2010) The role of nitric oxide synthase inhibition by asymmetric dimethylarginine in the pathophysiology of preeclampsia. Gynecol Obstet Invest 69: 1-13.

86. Cooke JP (2004) Asymmetrical dimethylarginine: the Über marker? Circulation 109: 1813-1818.

87. Achan V, Broadhead M, Malaki M, Whitley G, Leiper J et al. (2003) Asymmetric dimethylarginine causes hypertension and cardiac dysfunction in humans and is actively metabolized by dimethylarginine dimethylaminohydrolase. Arteriosclerosis, Thrombosis, and Vascular Biology 23: 1455-1459.

88. Böger RH1, Bode-Böger SM, Szuba A, Tsao PS, Chan JR, et al. (1998) Asymmetric dimethylarginine (ADMA): a novel risk factor for endothelial dysfunction: its role in hypercholesterolemia. Circulation 98: 1842-1847.

89. Holden DP, Fickling SA, Whitley GS, Nussey SS (1998) Plasma concentrations of asymmetric dimethylarginine, a natural inhibitor of nitric oxide synthase, in normal pregnancy and preeclampsia. American Journal of Obstetrics \& Gynecology 178: 551-556.

90. Ellis J, Wennerholm UB, Bengtsson A, Lilja H, Pettersson A, et al. (2001) Levels of dimethylarginines and cytokines in mild and severe preeclampsia. Acta Obstet Gynecol Scand 80: 602-608.

91. Braekke K, Ueland PM, Harsem NK, Staff AC (2009) Asymmetric dimethylarginine in the maternal and fetal circulation in preeclampsia. Pediatr Res 66: 411-415.

92. Savvidou MD, Hingorani AD, Tsikas D, Frölich JC, Vallance P, et al. (2003) Endothelial dysfunction and raised plasma concentrations of asymmetric dimethylarginine in pregnant women who subsequently develop pre-eclampsia. The Lancet 361: 1511-1517.

93. Bahtiyar MO, Buhimschi C, Ravishankar V, Copel J, Norwitz E, et al. (2007) Contrasting effects of chronic hypoxia and nitric oxide synthase inhibition on circulating angiogenic factors in a rat model of growth restriction. American Journal of Obstetrics \& Gynecology 196: e1-e6.

94. Yallampalli C, Garfield RE (1993) Inhibition of nitric oxide synthesis in rats during pregnancy produces signs similar to those of preeclampsia. American Journal of Obstetrics \& Gynecology 169: 1316-1320.

95. Petraglia F, Florio P, Nappi C, Genazzani AR (1996) Peptide signalingin human placenta and membranes: autocrine, paracrine, and endocrine mechanisms. Endocr Rev 17: 156-186.

96. Hillhouse EW, Grammatopoulos DK (2002) Role of stress peptides during human pregnancy and labour. Reproduction 124: 323-329.

97. Petraglia F, Potter VA, Cameron A, Sutton S, Behan DP, et al. (1993) Corticotropin-releasing factor-binding protein is produced by human placenta and intrauterine tissues. J Clin Endocrinol Metab. 77: 919-924.

98. Woods RJ, Grossman A, Saphier P, Kennedy K, Ur E, et al. (1994) Association of human corticotropin-releasing hormone to its binding 
protein in blood may trigger clearance of the complex. J Clin Endocrinol Metab 78: 73-76.

99. Petraglia F, Florio P, Benedetto C, Gallo C, Woods RJ, et al. (1996) High levels of corticotropin-releasing factor (CRF) are inversely correlated with low levels of maternal CRF-binding protein in pregnant women with pregnancy-induced hypertension. J Clin Endocrinol Metab 81: 852-856.

100. Florio P, Imperatore A, Sanseverino F, Torricelli M, Reis FM, et al. (2004) The measurement of maternal plasma corticotropin-releasing factor (CRF) and CRF-binding protein improves the early prediction of preeclampsia. J Clin Endocrinol Metab 89: 4673-4677.

101. Lacroix MC1, Guibourdenche J, Fournier T, Laurendeau I, Igout A, et al. (2005) Stimulation of human trophoblast invasion by placental growth hormone. Endocrinology 146: 2434-2444.

102. McIntyre HD, Serek R, Crane DI, Veveris-Lowe T, Parry A, et al. (2000) Placental growth hormone (GH), GH-binding protein, and insulin-like growth factor axis in normal, growth-retarded, and diabetic pregnancies: correlations with fetal growth. J Clin Endocrinol Metab 85: 1143-1150.

103. Lacroix MC, Bolifraud P, Durieux D, Pauloin A, Vidaud M, et al. (2002) Placental growth hormone and lactogen production by perifused ovine placental explants: regulation by growth hormone-releasing hormone and glucose. Biol Reprod 66: 555-561.

104. Lacroix MC1, Guibourdenche J, Frendo JL, Muller F, Evain-Brion D (2002) Human placental growth hormone--a review. Placenta 23 Suppl A: S87-94.

105. Chellakooty M, Vangsgaard K, Larsen T, Scheike T, Falck-Larsen J, et al. (2004) A longitudinal study of intrauterine growth and the placental growth hormone $(\mathrm{GH})$-insulin-like growth factor I axis in maternal circulation: association between placental GH and fetal growth. J Clin Endocrinol Metab 89: 384-391.

106. Chellakooty M, Skibsted L, Skouby SO, Andersson AM, Petersen JH, et al. (2002) Longitudinal study of serum placental GH in 455 normal pregnancies: correlation to gestational age, fetal gender, and weight. J Clin Endocrinol Metab 87: 2734-2739.

107. Wu Z, Bidlingmaier M, Friess SC, Kirk SE, Buchinger P, et al. (2003) A new nonisotopic, highly sensitive assay for the measurement of human placental growth hormone:development and clinical implications. J Clin Endocrinol Metab 88: 804-811.

108. Sifakis S, Akolekar R, Kappou D, Mantas N, Nicolaides KH (2012) Maternal serum placental growth hormone at 11-13 weeks' gestation in pregnancies delivering small for gestational age neonates. J Matern Fetal Neonatal Med 25: 1796-1799.

109. Mittal P, Espinoza J, Hassan S, Kusanovic JP, Edwin SS, et al. (2007) Placental growth hormone is increased in the maternal and fetal serum of patients with preeclampsia. J Matern Fetal Neonatal Med 20: 651-659.

110. Sferruzzi-Perri AN1, Owens JA, Pringle KG, Roberts CT (2011) The neglected role of insulin-like growth factors in the maternal circulation regulating fetal growth. J Physiol 589: 7-20.

111. Forbes K, Westwood M (2008) The IGF axis and placental function. A mini review. Horm Res 69: 129-137.

112. Vatten LJ, Nilsen TI, Juul A, Jeansson S, Jenum PA, et al. (2008) Changes in circulating level of IGF-I and IGF-binding protein-1 from the first to second trimester as predictors of preeclampsia. Eur J Endocrinol 158: 101-105.

113. Rechler MM, Clemmons DR (1998) Regulatory actions of insulin-like growth factor-binding proteins. Trend Endocrinol Metab 9: 176-183.
114. Sifakis S, Akolekar R, Kappou D, Mantas N, Nicolaides KH (2010) Maternal serum insulin-like growth factor-I at 11-13 weeks in preeclampsia. Prenat Diagn 30: 1026-1031.

115. Sifakis S1, Akolekar R, Kappou D, Mantas N, Nicolaides KH (2011) Maternal serum insulin-like growth factor-binding protein-1 (IGFBP-1) at 11-13 weeks in pre-eclampsia. Prenat Diagn 31: 196-201.

116. Sifakis S, Akolekar R, Kappou D, Mantas N, Nicolaides KH (2012) Maternal serum insulin-like growth factor-binding protein-3 (IGFBP-3) at 11-13 weeks in preeclampsia. J Hum Hypertens 26: 253-258.

117. Mohan A1, Asselin J, Sargent IL, Groome NP, Muttukrishna S (2001) Effect of cytokines and growth factors on the secretion of inhibin A, activin A and follistatin by term placental villous trophoblasts in culture. Eur J Endocrinol 145: 505-511.

118. Muttukrishna S, Knight PG, Groome NP (1997) Activin A and inhibin A as possible endocrine markers for pre-eclampsia. Lancet 349: 1285-1288.

119. Muttukrishna S, North RA, Morris J, Schellenberg JC, Taylor RS, et al. (2000) Serum inhibin and activin A are elevated prior to the onset of preeclampsia. Hum. Reprod 15: 1640-1645.

120. Kim SY, Ryu HM, Yang JH (2006) Maternal serum and amniotic fluid inhibin A levels in women who subsequently develop severe preeclampsia. J Korean Med Sci 21: 452-456.

121. Florio P, Reis FM, Pezzani I (2003) The addition of activin A and inhibin A measurement to uterine artery Doppler velocimetry to improve the early prediction of pre-eclampsia. Ultrasound Obstet Gynecol 21: 165169.

122. Davidson EJ1, Riley SC, Roberts SA, Shearing CH, Groome NP, et al. (2003) Maternal serum activin, inhibin, human chorionic gonadotrophin and alpha-fetoprotein as second trimester predictors of pre-eclampsia. BJOG 110: 46-52.

123. Spencer K, Yu CK, Savvidou M, Papageorghiou AT, Nicolaides KH (2006) Prediction of pre-eclampsia by uterine artery Doppler ultrasonography and maternal serum pregnancy-associated plasma protein-A, free beta-human chorionic gonadotropin, activin $A$ and inhibin $A$ at $22+0$ to $24+6$ weeks' gestation. Ultrasound Obstet Gynecol 27: 658-663.

124. Wald NJ1, Morris JK, Ibison J, Wu T, George LM (2006) Screening in early pregnancy for pre-eclampsia using Down syndrome quadruple test markers. Prenat Diagn 26: 559-564.

125. Spencer K, Cowans NJ, Chefetz I, Tal J, Meiri H (2007) First-trimester maternal serum PP-13, PAPP-A and second-trimester uterine artery Doppler pulsatility index as markers of pre-eclampsia. Ultrasound Obstet Gynecol 29: 128-134.

126. Nicolaides KH, Bindra R, Turan OM, Chefetz I, Sammar M, et al. (2006) A novel approach to first-trimester screening for early pre-eclampsia combining serum PP-13 and Doppler ultrasound. Ultrasound Obstet Gynecol 27: 13-17.

127. Poon LC, Kametas NA, Maiz N, Akolekar R, Nicolaides KH (2009) Firsttrimester prediction of hypertensive disorders in pregnancy. Hypertension 53: 812-818.

128. Akolekar R, Minekawa R, Veduta A, Romero XC, Nicolaides KH (2009) Maternal plasma inhibin A at 11-13 weeks of gestation in hypertensive disorders of pregnancy. Prenat Diagn 29: 753-760.

129. Akolekar R, Zaragoza E, Poon LC, Pepes S, Nicolaides KH (2008) Maternal serum placental growth factor at $11+0$ to $13+6$ weeks of gestation in the prediction of pre-eclampsia. Ultrasound Obstet Gynecol 32: 732-739. 